\title{
The Provision of Officers and Men for the King's Army
}

\section{Colonel W. T. Dooner p.s.C., A.A.G.}

To cite this article: Colonel W. T. Dooner p.s.C., A.A.G. (1901) The Provision of Officers and Men for the King's Army, Royal United Services Institution. Journal, 45:279, 509-540, DOI: 10.1080/03071840109417596

To link to this article: http://dx.doi.org/10.1080/03071840109417596

\section{册 Published online: 11 Sep 2009.}

Submit your article to this journal $2 \pi$

Џ Article views: 5

Q View related articles $\widetilde{2}$ 


\title{
THE PROVISION OF OFFICERS AND MEN FOR THE KING'S ARMY.
}

\author{
Bj, Colont IV. T. DOONER, p.s.c., A.A.G., Thames District.
}

\author{
Wednesday, 13th Xarch, 1901. \\ Lieut.-Colonel Lord RigLAx, Under-Secretary of State for War, \\ in the Chair.
}

NEARLY ten years ago, in the theatre of the old building, I had the honour of delivering a lecture on the "Recruiting Question and our System of Fnlistment," and I now venture again to appear before you to call your attention to a somewhat similar subject. We move slowly in this country of ours in connection with military matters, but, thanks in a great measure to the Institution in which we are assembled to-day, we do move. In the paper to which I have referred I made several suggestions, many of which were adopted, and with your permission I shnuld like to refer very briefly to some of them.

One of the chicf objects I had in view ten years ago was to make our Army as voluntary as possible, and to devise a system by which men who were so desirous should join the colours for three years and then pass to. the Reserve. I also asked for an increase of pay for some of the non-commissioned officers, and all the rank and file, and I suggested that a much better use conld be made of the deferred pay, as it was then issued, that "irresistible inducement" which was held out to the men to tempt them to go into the Reserve, and I ventured to point out that it should be abolished.

Some further proposals were made with a view of removing what some of the men looked on as grievances, such as having to jay for seakits when they were called on to embark for India or the Colonies, and that the worn-out clothing should become the property of the men; both these suggestions, I am pleased to add, were acted on, and, as far as the Regular Army is concerned, recruits are not now clothed in the derelict garments of some unclean predecessor. I also urged that those noncommissioned officers who held lance rank, and cspecially the lancecorporals, should be granted some extra pay. In 1891, there were no 
paid lance-corporals allowed to a battalion or unit. A short time after an order was issued allowing forty paid lance-corporals per battalion, or five per company. I also suggested that it was absurd, that before a maan could be discharged from the Army for bad conduct, his commanding officer must describe his character as "incorrigible and worthless," and that misconduct ought to be quite sufficient. The word "misconduct " was soon afterwards inserted in the Queen's Regulations, and in Section 32 of the Army Act, as a sufficient cause for discharge. I further pleaded, and this was my chief contention, that the soldier's position should be onc shilling a day and all found.

Seven is supposed to be a lucky number, and it took exactly seven years to get all these proposals adopted. It was not, however, until nearly three years ago that the citadel was carried, and that the last and most important proposal was adopted by the Secretary of State for War.

Lord Lansdowne, in April, 1898, abolished deferred pay, and instituted a system of giving certain of the men one shilling a day. Unfortunately, however, the boon was hedged about with so many conditions, that it is very doubtful if it has assisted recruiting in the slightest; with some flourish it was announced that all ranks excepting warrant officers were to get an increase of $3 \mathrm{~d}$., which was called messing allowance; but it was also ordered that the men were not to be permitted to draw this allowance until they were 19 years of age, and that they must also be reported on as efficient soldiers by their commanding officers. It was also directed that men who enlisted for three years' colour scrvice, were not to be given the allowance.

I do not know what could have possessed the authoritics to have ordered these conditions, as the result from a recruiting point of view has been more or less disastrous. Some delver in finance, I suppose, had something to do with it; but to anyone who understands the ordinary class of man which enlists, the object is that on the first pay-clay the recruit may realise that the Army is not so badly paid, and that he may then go out amongst his friends and tell them exactly how matters stand as regards his emoluments. . Some unwise adviser, however, of the Secretary of State, successfully impressed on Lord Iansdowne that a very excellent way of saving a comparatively small sum in the Army Estimates would be to bind the increase of messing allowance about with the conditions I have mentioned, and it was discovered, that by doing so there would be a saving to the public purse in the pay of all soldiers during the first year of their service.

Beforc April, 1808, a soldier received the shilling a, day, less his messing and other deductions, but he also was given $£ 3$ a ycar deferied pay. When the change was inade, the $\ell^{3}$, a year deferred pay was abolished, and a gratuity of $£ 1$ for each year of service was instituted. Thus a man enlisting at 18 now receives $f:$ less a year than he did formerly for the first year of his service; and therefore during his first twulve months in th: Arny; three of which he usually serves at the depot, every soldier is really worse off than he was before the change was made. 
The effect of this system has not been to improve the recruiting of the Army, as was apparently expected; and, one by one, sliglit modifications have had to be made in place of at once recognising the inevitable, and putting all officers commanding regimental districts and recruiting officers in the position of informing every intending recruit that he will reccive his clear shilling a day from the day of enlistment.

First let me deal with the age question, that no man is to receive this messing allowance until he is 10 years of age. The effect of this order is that all men enlisting are tempted to saj they are 19 ; of gourse, if they understand the Regulations thoroughly they will all give their age as 18. ycars, bccause, in addition to the age condition, a man has, as I have mentioned, to be considered efficient by his commanding officer. The authorities have practically ruled that being efficient means that a man must have six months' service, by which time. it will be assumed that he has learned his drill, musketry, etc. My hearers will therefore understand that the official age for all recruits to enlist at is 181 , so that a nian on rcaching his official ninetecnth birthday may become entitled to his messing allowance of $3 \mathrm{~d}$. a day; the men therefore are more than ever tempted to swear falsely regarding their age and make themselves older than they really are.

I am not here to-day to lay before you, or to ask you to discuss any' great scheme of Army Reform, or to make any proposals which will upset or injuriously affect our present system. For a voluntary Army like ours I think the present system of enlistment, which allows the men as far as possible (if their conduct is satisfactory) to do exactly as they please, within certain limits, regarding their time with the colours is an cxcellent one; and if some slight improvements were made involving a little cxtra expense, I think it would be found that we should get sufficient officers and men for the wants of our Empire.

There will probably be different opinions regarding what the wants of our Empire may be. Our Army, in comparison with foreign Armies, is, of course, ludicrously small ; including Regulars, Militia, Voluntecrs, Colonial troops, and all other sorts of men we can by any stretch of imagination call soldiers, we only have about 2$\}$ soldiers to every 1,000 of population, while France has 112 and Germany about 60 . The total population of the Empire is about $380_{4}^{1}$ millions, and our total Army scarcely reaches 900,000 , while the area of the Empire is nearly 12,000,000 squ tre miles. I an presuming, however, that after the South African Var is finished matters will gradually settle down as they were before it commenced, with an increase of a small permanent garrison for South Africa, probably $5,000 \mathrm{men}$ in addition to the former garrison of the Cape and Natal.

There would be nothing gained to-day by my referring to the organisation of our Regular and Auxiliary Forces, nor by asking you to discuss the advantage in having between 300,000 and 400,000 . Iilitia and Volunteers with uniform on their backs and rifles in their hands, not thoroughly trained, nor supplied with the proper proportion of cavalry, artillery, transport, or medical arrangements. I will not ask you to con- 
sider whether an armed crowd firing rifles from behind hedgerows is to be consideretesufficient for the defence of these islands; nor will I refer to the question decmed so necessary by many, but which 1 think would be a terrible waste of public money, viz., that three army corps should always be ready for inmediate embarkation. To have eren one army corps always ready to go on board ship, I venture to think would be quite unnecessary, and would add enormously to the Army Estimates, as the ships must be ready also, and these vessels would possibly be out of date before they would be required. The recent mobilisation proved how unnecessary. such a regulation or order would be. In many cases, divisions were mobilised, and, in order to cause as little inconvenience as possible to the men, ten days were given to them to report themselves. It was found that almost all joined on the last day named in the order, but after this date many of the battalions were frequently on board ship within three to seven days, and on their way to South Africa. IVith such an experience, what would be the object of keeping such a force as eren one army corps always prepared and ready for embarkation?

I will not bring before you the wisdom or otherwise of weighting men in marching order with 60 lbs. or more, and then expecting them to march 15 or 20 miles and fight a battle at the end of it. I thare no intention of making allusion to our army corps organisation borrowed from our Continental neighbours, and whetler it is suited to our requirements. In South Africa it fell to pieces at once. All thes: matters must be dealt with by others. l3ut acting on the principle that there is no use in bringing forward any scheme of Army reform for our Regular Armj unless you have an Army to reform, I have decided to-day to ask your consideration for only two matters-our officers and soldiers, and how to obtain them. It seems a suitable time to do so, as owing to the war in South Africa the question of how to find drafts for India and the Colonics is already reaching an acute stage.

Conscription. - There are, it is recognised, two methods of obtaining an Army: either by some form of compulsion or voluntarily. Our 'Army is, 'I think, happily a voluntary one, and I trust will ever remain so. Voluntcers are always to be preferred to pressed men, and I have always considered it a grand idea that in our Army there is not one man in it who is not there of his own free will, Conscription or any form of compulsory service has not yet, I venture to hold, come within the region of practical politics, and there does not appear to be the slightest, prospect of any Government proposing its adoption in these islands, until it is shown conclusively that the voluntary system has failed. I am not aware that any Member of Parliament has ever ventured even to allude to such a subject as compulsory service in his address to his constituents. Conscription, or any form of compulsion, is at present a'gainst the feeling of the English people; in their present temper they will not have it, and it is exceedingly doubtful if there is any necessity for it. The nation will consent to pay any reasonable sum to have a voluntary Army, and 
the great majority of the prople have most liberal views with regard to the payment of our soldiers. If it is considered necessary to increase the Estimates to get officers and men, there is never any opposition to any reasonable proposal asked for by the responsible Minister, and declared to be for the good of the Service. I, therefore, will not detain you further by referring to conscription; the experience gained two years ago, when even the Militia Ballot Act nas referred to in the Housc of Lords by Lord Lansdowne, ought to be sufficient answer to those who hold the riew that compulsory service for even home defence is in the least likely to be proposed in the near future by any Government. There appears to be no probability of such a Bill being brought forward. Some of us military men may dream or hope for such a constimmation as compulsory service for home defence, but the political barometer does not point in such a direction, and I scarcely think I need dwell any longer on this subject.

Officers.-I will, therefore, at once draw your attention to the means adopted to get our officers and men under a voluntary system. As regards the officers, there will always be an ample supply, and the method adopted of passing cadets through Woolwich and Sandhurst, and allotting a proportion of vacancies to the Militia, works well. It does not seem as if there is any intention to make any change, and the system or systems, if only given fair play, would mect all our requirements. Sandhurst and Woolwich have always yielded good results, and the only question is, should officers be permitted to enter the Regular Army through the Militia. I beg to answer in the affirmative; it is an excellent arrangement, both in time of peace and in time of war, for the Militia and Regular Army. In peace it keeps the ranks of the Militia more or less full, and would always keep them complete if only those in authority could make up their minds as to how many vacancies for the Regular Army can be allotted yearly to the Militia: In some years the commissions granted have fallen as low as 80 for the Line, 40 being allotted half-yearly; while on other occasions the number has risen to 200 or more, and as a consequence a candidate does not know what amount of competition he will have to face. It would be exceedingly easy to allot 75 , or perhaps more, infantry of the Line. commissions half-yearly to the Militia, and let it be known that this number would never be decreased; this would be a fair proportion and would have an excellent effect in kecping the battalions of that force up to their strength in officers. If 150 or 200 . candidates go up for these 75 or more vacancies, as would generally be the case, so much the better for the country and for the. Militia. It must be recollected that all the candidates competing are excecdingly well instructed in the military subjects by those who have prepared themso-called crammers-a term which has litile meaning, but which I am inclined to definc as men who know their business. These instructors have to rely on their teaching as a profession, and, if unsuccessful, their pupils decrease in numbers. The candidates also must have served two trainings with their battalions. I have found-perhaps, it depends on the Militia battalion to which they belonged, the commanding officer, adjutant, etc.- 
that the majority of Militia candidates were sufficiently prepared to take their places in the ranks on joininer, and were fit for duty. One thing is very certain, that in the military subjects these officers have been hitherto exceedingly" well informed. The winter sketching or the promotion examinations are little or no trouble to them, and in $\mathrm{my}$ opinion the system of officers getting commissions through the Militia cusures our having in that force a very fairly instructed body of young officers; and we get the pick of them for the Line. Some have called these candidates for the Regular Army " birds of passage," and they may be so designated, but it must be recollected that the so-called birds of passage have hitherto had a good knowledge of topography, military law, fortification, and tactics; they are on the strength of their battalions, and available when called on should war break out. The present leader of the Opposition, when Secretary of State for War, called this system of officers entering the Army through the Militia a back door; but I should, indeed, like to be informed by that distinguished statesman, or anyone else, how in the end of 1899 , when it became evident that the war in South Africa would be prolonged, and when it was found that the army corps sent out was quite insufficient for the task before it, officers would have been found to fill the war casualties occurring at the front, and the vacancies in the battalions ordered abroad, if we had not had the Militia, this so-called back door, to fall back upon. But for that force we should not have had an instructed candidate of any kind; those studying at Sandhurst were almost immediately: drawn upon and absorbed. Some of the battalions of the Regular Army on the peace establishment were eight or nine officers short of their required numbers when they received the order to mobilise. Sandhurst could not furnish sufficient, but fortunately we had the Militia to help, and commanding officers of battalions were called on to recommend officers for the vacancies; many of those who were so recommended had qualified at the Competitive Examination, having failed, pcrhaps, by only a few marks; and I am sure the knowledge they had gained from their various private instructors was of the greatest value to them while on active service.

The only objection to this system which I am aware of is that a Militia battalion may suddenly find itself short of three or four subalterns, should that number be successful in the Competitive Examination. This, in time of war is, perhaps, a serious consideration, but it can be practically avoided, and at little expense to the public, by adopting a proper and consistent organisation for the MIilitia, viz., that each company should have two subalterns instead of the present extraordinary system of an average of 11 of a subaltern. Each battalion of eight companies under the existing arrangement is entitled to have one subaltern per company, and also four per battalion extra are allowed; thus an eightcompany battalion has twelve subalterns. This organisation is meaningless. A company should either have one subaltern or two, but there can be no sense in having $1 \frac{1}{2}$. By far the better organisation is two per company, and the experiences in South Africa show that this number is absolutely necessary. In peace, it is true, a company can get alorig 
with one subaltern officer, but on active service two are a necessity. An eight-company battalion, therefore, ought to have sixteen subalterns, and then, if it should happen that two or three officers passed into the Regular Army at an examination, the work in peace-time could still be carried on efficiently and without difficulty.

The object of the State should be to have as many trained and wellinstructed officers as possible ready for any emergency, and this system of having Militia officers ready is an excellent one. I suppose, also, a more cconomical one could not possibly be devised, as the expense to the public annually under normal circumstances of training a Militia subaltern is $£ 14$ or $£ 15$, his pay and allowances for 27 days. All his other instruction in the military subjects is carried out at his own cxpense. Therefore, the extra cost for four more subalterns per battalion would be about $£ 00$ per annum, or lesss, to the State.

While on the subject of the Militia and the system of supplying officers therefrom for the Regular Army, may I mention that it would be far more convenient for battalions, and a comfort to commanding officers, if the half-yearly spring examinations could be held at any other time than in March? By holding the examination in March the result is usually announced at the end of April or beginning of ilay, just as all the battalions are being called out for their trainings. A commanding oflicer thus, at the most important time of the year, just as his battalion is assembling for training, finds himself, under the cxtraordinary organisation I have mentioned, short, possibly, of two or three subalterns. 'There is no time to replace them, and even if a candidate for any vacancy can be found he is quite untrained, and knows nothing whatever of his drill or duty, in fact, is more or less of an encumbrance. Thus commanding officers, through no fault of their own, have this extra difficulty to contend with, of their, battalion coming out for training short of officers. It would be far preferable if the examination could be held early in February, the result bcing announced as soon as possiblc, so that there may be a chance of filling the vacancies, and that the candidates may get some little instruction at the depot before the battalions assemble. The autumn examination is not so important, and it is immaterial whether it is held in August or September.

Military Messes and Bands.-As I am dealing with the question as to how officers are to be obtained for the Army, and as the expense of living in the Service largely enters into this subject, the question of military messes deserves some notice.

There is no reason in the world, which I am aware of, why a wellmanaged military mess should not be the cheapest and most economical place in the world to live in, and it is to be hoped, for the'sake of the officers of the Army, that regimental messes will never be abolished. The regulations concerning their management are excellent, and in a measure just to all concerned, and if carried out, in spirit as well as in letter, I think that even subalterns with a reasonable allowance would be able to live well and comfortably. 
There is a sort of recognised rule in some corps of the Army-there is no regulation, I belicve, on the subject-that the messing should not exceed 4s. per diem; in some well-managed corps it is slightly less. It can easily be done for this sum if there are twelve or fifteen dining members. . I have catered for officers and fed them well for less than $4 \mathrm{~s}$. per day, but it requires much supervision, and entails a visit each morning to the larder and kitchen, and a careful inspection of the bill of fare and tradesmen's books.

I wish to let all commanding officers know that it can be done in most stations for $4 \mathrm{~s}$, and the best way, in my opinion, to get it carried out is to livide the duties of the NIess Committee. The president should superintend the accounts, and the other two members, instead of, as is usual, doing in reality nothing, should supervise, one the catering, while the other member should look after the wine-cellar. This is a fair division of labour, and the commanding officer should exempt certainly the caterer from any regimental work possible.

We start then with the necessary expenses of $4 \mathrm{~s}$. a day for a young officer, and in addition he will have to pay, as mentioned in the Regulations, in subscriptions, 10 s. to $15 \mathrm{~s}$. a month-in some corps this amount is divided under different headings, but it all suins up the same; possibly also there may be some small subscriptions to cricket and rifle clubs; but the total compulsory payments, including mess guests, need not necessarily exceed $\oint^{7}$ to $£_{7}$ ós. per month. The item "mess guests" in some regiments is small, especially for subalterns, if the Regulations are carried out, and also that care is taken to test every small expense charged to this item. It is ludicrous to find how much is put down uncler this heading daily, unless proper supervision is exercised : and if care is taken, it will be found that the expense will decrease to an enormous degrec. As to large entertainments, it is a question for the commanding officer and those belonging to the corps; it would be useless my entering into then, and any subscription to them is voluntary.

I have thus shown that in a well-ordered regimental mess the compulsory payments are about $£ 7$, or slightly more, per month, and if we add to this sum $£ 2$ to $£ 3$ for wine-some officers incur much less under this heading - there is no reason why an officer should have to pay for his mess bill more than about $£ 9$ to $£ 10$ per month. I have many times looked at the mess-book of $\mathrm{my}$ battalion and depôt, and found it about this amount, or considerably less for a careful oflicer.

I could give many and amusing examples of the letters I have reccived from fond parents of young officers concerning their, sons' mess bills, but I invariably made the same reply that if their sons could not get on without drinking champagne and other similar wines, smoking expensive cigars, and also insisted on injuring their dinners by eating enormous and unnecessary teas, naturally their mess bills would be high, but that I hardly thought it my duty to interfere.

While on the subject of officers' messes, I might, perhaps, mention -some commanding officers might like to know it-a system by which 
accounts can be examined quarterly, before the usual mess meeting, in a very easy manner. The great point is, to take care that the mess fund and the catering fund are kept quite distinct. If they are kept in one account, it is a great source of confusion and irregularity. With regard to the catering, it is only a matter of secing that the tradesmen's bills and the cooks' wages are paid. Regarding the mess fund, it is quite easy to direct the mess president to send to the orderly-room by the 10 th or 12 th of the first month of each quarter a statement, showing on onc side the receipts credited to the mess fund, and on the other side the charges against that fund; and by this the balance credit is seen in a moment. On one side should be shown the receipts, such as officers' subscriptions and donations credited through Messrs. Cox \& Co., also the usual King's allowance of $£ 24$ per annum per company, the monthly subscriptions of officers, and any profit on wine, etc. I shall, probably, surprise many when I say that this all adds up to over $\$ 500$ a year, and is for keeping the mess in order, paying servants' wages, liveries, newspapers, and furniture, and, as the Regulations direct, for decreasing the cost of wines. This sum, if well looked after, is sufficient. It must be added, however, that it is scarcely fair of the Regulations to order the deductions of eight days' pay a year, which are made for the mess, and the twelve days' pay which are deducted for the band; thus, the officers have twenty day's' pay taken from them nolens zolens crery year. It is bad enough to have to pay large contributions of thirty day's' pay to the mess and twenty days' pay to the band on joining a corps, but, in addition, to have to pay these subscriptions is very unreasonable. Thus, if we take an unmarried major, he will have paid an entrance of fifty days' pay at 16 s. to the mess and band-total $£^{40}$; in addition, he has to pay annually twenty days' pay of $£ 16$. Similarly, an unmarried captain will have paid $£ 29$ 9s. 2d. entrance, and is mulcted annually in f11 11s. 8d. Messes and bands are essential for the credit of the Service, and the Government should assist. It must be recollected also that officers of the Army, especially when stationed abroad, frequently entertain foreigners, and the officers of ships of other nations, for the credit of their regiment, the Army, and the nation, to which we all belong. The Government might well help by giving each corps a small grant of about $£ 100$ a year to the officers' mess, to be called an entertainment or table allowance, and directing that in future the subscription of eight day's' pay per annum will not be deducted from each officer.

The deductions from the pay of officers to keep up a band should ccase; it is scarcely fair if the State consider a band necessary for each unit, that, in addition to the large contributions I have referred to a lieut.-colonel should also have to pay $£ 74 \mathrm{~s}$. per annum, a major $£ 68 \mathrm{~s}$, and a captain $£ 4$ 12s. $8 \mathrm{~d}$, in order to keep the band going.

Why Lord Cardwell should have consídered it right to exempt the subalterns from this tax, but to have decided that the captains and field officers should:be mulcted in the way they are, has always been a mystery 
to me. It is to be hoped that this order will disappear from the next issue of the King's Regulations.

With regard to officers, therefore, and the expense of living in the Army, I hope I have shown that in a well-ordered battalion; and with the charges regarding mess and band subscriptions, which I have suggested, removed, it would not be difficult for a subaltern in the infantry to live on his pay and about $£ 100$ a jear. If he has more, so much the better, he can then indulge his tastes and hunt or play polo; but it is ridiculous to say that these are necessities. If any increase of pay is decided on it should be given to those who gain field rank or become conmanding officers; much is expected of the latter, but their pay and emoluments are absurdly small. No one starting at any professionlawyers, clergymen; medical men-can possibly, for some years, hope to make both ends mect. Serjeant IBallantine stated he did not make bread. and chcesc for many years; and it is unreasonable for parents, because their sons jass out of Woolwich or Sandhurst, and get their commissions, to therefore conclude they will not need further pecuniary assistance. In normal times promotion is slow, and an officer may not gain his company for ten or twelve years-many of my hearers were probably twelve years or nore in getting their captain's rank-in such cases some increasc of pay after seven years, not ten years as it usually works out, might be granted till the captain's rank is reached.

Instruction of Militia and Volunter. Offeers.-Before I leave the subject of the officers of the Army, may I mention, with regard to the Militia and Volunteers, that the officers do not get much encouragement to learn their-duties. The difficulties in their way are very great. They often have to apply many weets, or sometimes months, before a class will asscmble in order to get leave to attend it, and when, perhaps, after long delay owing to the routine which has to be gone through, the permission is given, it is then too late for them to upset all their private arrangements or business, and they cannot attend. If their time is valuable, as it is in many cases, they cannot wait while replies are filtering through all the various offices. They should be encouraged in cvery possible manner to improve their military education, and with a view of doing this all captains of Militia and Volunteers who succecd in passing the usual cxamination for promotion to higher rank in the subjects referred to in the Regulations as $(C)$ to $(G)$, should be given some reward for doing so. The authorities would, I think, be well advised in offering some fee like $2 \dot{j}$ gumeas or more to all Militia and Voluntec captains who pass these examinaiions for higher rank, as we should then, in a short time, have well-educated officers in the Auxiliary forces, who, in times of diffculty like what we have gone through in the last eightecn montlss, would be available and fit for almost any employment. Of course, in the case of the subalterns, if aly fee is given, it need not be so much as for captains, as very many of the subalterns who have been candidates for the Army will find less difficulty in passing the ordeal. In the case of captains every encouragement should be given to them, and 
those officers who are successful should always be selected first, and in preference to any other officers of the Auxiliary forces, for any appointment or employment which might be vacant and suitable.

Non-Commissioned Officers and Men.-Having thus discussed the question of officers, I now turn to the rank and file of the Army, and it must be evident, I consider, that what a man enlisting wants to know is, how much he will receive from the moment he joins the Army-not what he will receive after a year or more, provided he fulfils certain conditions, and which conditions he invariably thinks are hedged about with some sort of regulation which he docs not understand, and which he may not be able to fathom or be equal to. In April, 1898, when the new rules regarding messing allowance were issucd, in order to let them be well known in the regimental district I then commanded I published the following notice. It is hanging from the table:-

"All eflicient soldiers enlisted for seven years' colour service in the Regular Army now receive 1s. per day, and clothing and food frec, on reaching nineteen years of age."

I was compelled to insert the word "eflicient," as even men who enlist at ninctecn years of age, or indeed at any age, do not ant once reccive the shilling a day, but must, as already mentioned, wait until their commanding officer considers them efficient, which, being interpreted, means that they must, cxclusive of days of absence on leave or in hospital, have been under training for six months. This condition was, I think, most unwise and, from a financial point of view, an error. It only leads to misunderstanding on the part of the men, who, when they find out their mistake, get disappointed and absent themselves or desert; and when apprehended, the expense caused by escorts being sent for them, I imagine, far out-balances the saving, to say nothing of the injury done to recruiting by prisoners in plain clothes, and handcuffed, being sent with escorts all over the country. Fven Militia service, until quite recently, was not allowed to reckon in this six months required for efficiency; but now this barrier has been removed. I hope, however, it will be understood that a man who has not becn in the Militia, and who joins at nineteen or even twenty or later, does not receive the shilling a day until he has six months' service, and, possibly, even then he may not be granted it. Such rules and regulations are mistaken policy and false economy.

I have referred to the notice $I$ issued at $A$ rmagh when these rules came into force in April, 1898; what was the result? It was looked on with a little suspicion. In one of the battalions-it may have occurred in the others-of the Militia brigade; when out for training, and where I had these notices posted up, a discussion took place. I am afraid the men did not use the gentle language I am giving this audience, but it was to the effect : what did Colonel Dooner mean by an " efficient soldier"? It was only reasonable that such a question should be asked. But this will show you some of the difficulties recruiting officers have to contend with. The thinking men among our would-be recruits, the men who like to know what they are doing, and the men we want to encourage to enlist are 
deterred from joining, and possibly many a good soldier is lost to the Army.

It is the business of the officers of the Army to make a man efficient, and -if a recruit cannot be turned into a soldier, which does not often happen, he can be discharged. It may be added also that it is the business of the medical and approving officer to see that men before being accepted are of the necessary age and physique; and, therefore, I think the authorities would be well advised in deciding that, when once enlisted, the men should be given their clear 1s. a day pay.

There are two other stoppages which should be mentioned, and which all soldiers, irrespective of age or efficiency, have to pay. They are small items - the washing and hair-cutting-and these are still a charge against the private soldier. They do not amount to much, the former being $\frac{1}{2} \mathrm{~d}$. a day, in some coips a penny, the latter 1d. per month, or a total of about $1 \mathrm{~s}$. $4 \mathrm{~d}$. to $2 \mathrm{~s}$. $7 \mathrm{~d}$. monthly. It would be well if they could be paid by the public, and thus abolish every compulsory stoppage, so that the steady, careful soldier may know that he will get his pay without any deductions. If this were done, an Army notice could be issued that all men joining the infantry of the King's Army receive 1s. a day and are all found. Here would be a short unvarnished tale better than any animatograph or doubtful notices with long explanations, which invariably cause suspicion on the part of those who may read them and who are meditating enlistment. The bargain with those enlisting should. be free and open, so as not to leave the smallest loophole for grumbling. The question of the State paying for the hair-cutting is really not very important; it is, as mentioned, only 1d. per month, and the men have not much objection to paying it, as the total amount deducted from them goes to a comrade, the company.hair-cutter. It is not very material who pays it, the Government or the soldier; but I recommend the stoppage being done away with. To abolish it will involve about an extra $£ 10,000$ a year to the State.

The Militia.-Non-Commissioned Officirs and M/en.-I now come to the Militia, and as this old constitutional force is, as far as can be estimated, 20,000 or more under its establishment, and, as I venture to think; it is a very valuable part of our Army, and one to be encouragred in every possible way, I beg to maintain that it is a great mistake not to give the extra messing allowance of $3 \mathrm{~d}$. a day, irrespective of age and service, to all Militiamen. I have always impressed on all men enlisting to join the Militia first, in order that they may see for themselves what the discipline, pay, etc., of the Army is, and then, if they like the Service, they could decide on going on to the Regular Forces. This, however, is what we cannot let them, as far as pay goes, learn practically in barracks at the headquarters of a regimental district, as no Militia recruit, or, indeed, any recruit, can, in any possible way, from experience learn what the pay of the Army is. "Under present regulations a recruit cannot be paid more than about $8 \mathrm{~d}$. per day, and thus a Militiaman after his 49 days' drill goes away from the depôt with quite a wrong impression of the Army and its emoluments. 
I should mention here that Militia recruits are allowed to cnlist at, or after, 17 years of age, and therefore some of my hearers may say they should not get the clear shilling at that age. In connection with this point, however,-it must not be forgotten that during the first year of his service the State only pays the man for his 49 days' preliminary drill and 41 days' musketry and training-total, 90 days. The recruit then goes away, and has to earn for himself, as he cannot enlist in the Regulars till 18; he is, therefore, of no further expense to the State. Giving then each man the extra messing allowance for 90 days is only $£ 1.2 \mathrm{~s}$. $6 \mathrm{~d}$. each, and it would be money well spent, as the object is that the recruit should return to his village and tell exactly what pay he received. W'hen the total of the Army Estimates is considered, the extra expense of granting this mess allowance would, in the words of the prophet of over 2,500 years ago, be a mere drop in a bucket; but its being sanctioned would give cvery recruit drilling at the depot, and out for training, a truthful and clear idea regarding the Army and the soldier's pay; and this would be most useful, and assist recruiting greatly for the Regulars.

When a Regular or Militia recruit enlisted, and behaved well, and paid attention to his drill, etc., I always endeavoured to give him leave, when he could be spared, to go and see his friends and relations. This I always did, as regards the recruits for the Regular Army, giving them seven days furlough so that they could take their week's pay with them. In Ireland, also, the railway companies do not grant the return ticket for the single fare for soldiers unless the furlnugh is for seven day's. This giving, however, of short furloughs to Militia recruits during their preliminary drill or training, cannot be carried out ; as in thesc days of decentralisation an officer commanding a regimental district, or even the general officer commanding, cannot give a Militia recruit any leave excecding three days with pay without referring to the Secretary of State for Var. Of course, by the time the answer would be received the necessity for the leave would have passed; but the idea that a colonel or general officer conld not be trusted to give a recruit, whose mother or father might be dying, or dead, seven days' furlough with pay is almost comical. My object in giving recruits seven day's' furlough was to encourage them to learn their work and duty, and it is these men going to their villages, if they are contented and happy, who are the real recruiters for the King's Army. If a man goes to his relations for a week, and arrives home clean and smartly dressed with his week's pay and ration allowance, total 10s. 6 d., all his friends see for themselves, and the result from a recruiting point of view is sure to be satisfactory. I hope soon such men will also be able to take with them their messing allowance of $1 \mathrm{~s}$. $9 \mathrm{~d}$. per week, so that they may have a total of over $12 \mathrm{~s}$.

It is essential that men going on furlough should always arrive in their town or village with sufficient money. I could give many examples to prove my contention, but two will probably be sufficient. A steady good soldier of the Royal Irish Fusiliers went on furlough to a village in the Queen's County, and shortly after five men were one morning brought before me who had arrived to join the depot 
at Armagh, from the village where this man was on leave. I.hope it is understood that these men did not come before me for final approvalthat duty had been carricd out at Naas-but I made it a rule to sce and speak to every man who joined the depot, and also to ask him did he understand the small notice you see hanging from the table, and which was handed to every recruit in the receiving room. As these men came from Queen's County, I enquired why they had chosen the Royal Irish Fusiliers, and I found it was all the work of the man who had gone on furlough. These five men had made their way to Maryborough, were then passed on to Naas, and had been forwarded from there to Armagh ; they were, of course, reckoned in the recruiting returns as from the 102nd Regimental District-that is not very important-but while they were under my command at Armagh they never committed themselves, and I have no doubt they made excellent soldiers. They knew and had seen this man on furlough; he drew the messing allowance, and I think he had two good-conduct badges, and they came to the conclusion the Army was not so badly paid. Of course, when they came before me I had to explain to them concerning the 19 years of age and efficiency condition, and that they could not get the messing allowance for a year or so.

An exactly similar case occurred at Drogheda. I sent a man on furlough there, ard one morning three men came in, and the same. procedure had to be gone through. These two examples will show what well-conducted, fairly-paid men going on furlough may do for the recruiting of the Army: What we really want are contented soldiers, and this is the way to get them; they are the best advertisement for the Army. Of course, recruiting sergeants are a necessity to do all the required work of making a preliminary medical examination and then getting the men attested and forwarded to headquarters; but this, and giving advice, ought to be all that is necessary. What I should like to see is, outside all post-offices, a short but prominent notice of the kind I have mentioned, and that all men desirous of joining the Army should apply to the recruiting sergeant at wherever the nearest place may be. I think if the clcar shilling a day can be granted, and if a plain notice of the kind I refer to can be placarded through the country; it will not then be necessary for recruiting sergeants to be hanging about public-houses to try and enlist the sort of men who frequent such places.

Militia Bountics - The question of bounties to Militiamen requires some amendment; they ought to be increased, especially for Militia Reservemen-a most valuable body of men, and who have done their work well in South Africa. The bounty given to a recruit might also be better divided. At present the $f 2$ bounty is given-10s. at the conclusion of the preliminary drill, and $£ 110 \mathrm{~s}$. at the end of the training: This latter leads to misunderstandings, as at the end of other trainings the man gets only $\mathcal{E}^{1}$; a better arrangement would be to give each recruit $£ 1$ at the end of the preliminary drill, and $£ 1$ at the conclusion of the first training. This question of bounties, it may be mentioned, was dealt with by the Secretary of State on liriday evening last in the House of Commons. 
Those who argue that the Militia should not be used as a recruiting ground for the Line are, I venture to think, greatly in error; one writer in a recent article in a magazine likens the Militia to a milch-cow, and insists that the Regular Army must have its own methods for keeping its ranks full. To those who hold such views I would point out that the Militia is the only part of qur Service which a man can join and if he does not like the military life he can then under normal conditions purchase his discharge for the small sum of $f 1$. In the Regulars such a discharge costs $£ 10$ within the first three months of enlistment, after three months the expense is $f_{18}$. It is, therefore, evident that all men who are at all doubtful as to whether the life will suit them should at first join the Militia, and I always advised recruits to do so. It is for this reason that it is so desirable that Militiamen should be given exactly the same pay and allowances as men in the Regulars.

Annual Training.-The length of the annual training of the Militia requires some consideration. At present, owing to its only being about twenty working days, the musketry and all instruction are fearfully hurried. Thus the brigadier can never get an opportunity of teaching his brigade anything. I do not think it would inconvenience anyone, offeers or men, to extend it for one week to thirty-four days. This would then give some time for brigade work and practising the higher military subjects, such as outpost., attack, and defence, in a thorough manner. It is also most difficult to decide the best time for the annual training with due regard to recruiting. In the West of Ircland many recruits are lost if the trainings are not completed by the 1st June. The returns of the railway companies show that the number of tickets to harvest-men for England issued in June is enormous. Each of these men bring back to Ireland about $f_{10}$ each, and they cannot sacrifice this money. If, however, the present bounty was raised, and that the trainings could be got through earlier, which would, I fear, involve barracks being made available owing to the climate, a new source of supply would be tapped; and some of the West of Ireland battalions, now so much under establishment, would then possibly be able to increase their numbers. The fact is, local difficulties must be more weighed and considered; what applies in the West and North of Ireland is inapplicable to the South of England.

Emplojment of Resertemeit.-The subject of employment for the men on leaving the colours is, of course, very important, and has much to do with recruiting for the Army; but this question has made great strides for the better in recent years with all the numerous agencies now at work, and the patriotic way in which most large employers of labour take reserve and-discharged soldiers into their employment. In future years, however, I think it will be found that more men than formerly will remain with the colours; and this will be especially the case if the rules regarding foreign service are a little relaxed and that men are not kept so long abroad as at present: The existing Regulations direct that when a non-commissioned officer or man has completed six ytars' in India-formerly it was eight, with some exceptions-his name

VoL. XIT. 
can be registered to be brought home. This very often means that the man does not get home before seven years or more have elapsed, as the returns are not sent to War Office until the 1st July in each year. This regulation militates against men staying with the colours.

On one.occasion seven Reservemen were going through the usual three day's' drill on the parade ground at Armagh; six of the seven were well dressed and fairly satisfied with the civil employment they were in ; the appearance of the seventh spoke volumes'as to his character, and showed conclusively why he was not in satisfactory employment. I asked them all why they had left the colours; of course, the seventh man could not have remained even if he had been so desirou's, owing to his character, as I afterwards found out from his papers. They all gave the same replythey had been in Burmah and India for three, or four years, and they knew if they prolonged their service with the colours they could not get home for a change for some considerable time, so they went to the Reserve. I think, therefore, the Regulations I have referred to should be altered, and that all officers, non-commissioned officers, and men after five years' foreign service anywhere should be allowed; if desirous, to return home, and not be available again for foreign drafts for two years. The regulation. makes the period for the Mediterranean and other good stations as five years, and for India, as I have mentioned, six. This seems inconsistentprobably the expense of the passage has something to do with it-but with a voluntary Army, and also from a humane point of view, expense must not be considered.

It is clear that a man cnlisting for seven years, and then kept for the extra year, making eight in all, has to usually spend at least five or more of those years abroad, and if he is in an indifferent climate, even for health's sake he should get a change and be permitted, if he wishes it, to return to the home battalion or the depott.

The example I have given shows, I think, that Army Reservemen transferred with very good or exemplary characters are seldom out of employment, and that many of these men, now that the "irresistible inducement" of $£ 21$ to $£ 24$ is not given them to go into the Reserve, will remain with the colours if the tour of foreign service is reduced, as I suggest. Should the latter happen hereafter, it will always be easy to allow men so desirous, and in accordance with the exigencies of the Service, to go to the Reserve after threc or five years' service, so that the strength of the Reserve may be maintained.

Rejection of Recruits on Phy'sical Grounds.-Under the present standard of height, etc., laid down in the Recruiting Regulations, it is found that about 40 per cent. of the men offering themselves for enlistment are rejected on medical grounds, and among those rejections are many who would make most useful mounted infantry soldiers. At present a man enlisting for the Regular infantry must be 5 feet 3 inches in height, bụt a driver in the artillery is accepted if he is 5 feet 2 inches. The present rules regarding training mounted infantry will probably be considerably modified later on, and possibly a listinct force may be formed; but 
until this is done it would be well to allow 10 per cent. of men whe enlist for the Line to be taken at,.or over, 5 feet 2 inches, and let these men, if possible, be made into mounted infantry:

In the French Army the minimum height is 4 feet 11 inches, and it is possible it may be still further reduced, so if our minimum is made at 5 fect 2 inches or cven $\overline{5}$ feet we shall still be a considerable way off our neighbours, and small men are better for mounted infantry work; it is also very doubtful if height at any time is a test of physical endurance. Many of the Colonials fighting for us in South Africa, I understand, were scarcely 5 feet high-and how well they have done ! It is also well known that one, if not two, of our most distinguished generals would have been rejected when joining the Army had the present rules as to height and physique been in force.

I have had to refuse a large number of men because they were not the requisite height and weight, and have prevailed on many of them to join the Militia in the hope that they would grow to the necessary standard.

Frce-Discharges.-Recently a class of free discharge has been embodied in the Regulations, by which men are allowed to return to civil life if their parent or parents are destitute, and the soldier has any decided prospects of suitable employment. This class of discharge has increased largely of late, and causes considerable expense to the public. There is really no reason why the man should be discharged outright, and I do not see why in such cases his services should be totally lost to the State. If a man can really become the bread-winner for his mother or father, or assist them-and this is the case which usually occurs-there is no reason, if he is permitted to return to them, why he should not consent to join, if he is fully trained, the Reserve, or, if untrained, his local Militia battalion. 'He can easily arrange in the latter case to do his twenty-seven days' annual training ; and I would, thereforc, suggest that the paragraph in the King's Regulations should be altered accordingly. Instead of giving the man a free discharge, after the State has been put to much expense to clothe, feed, and train him, he should be transferred to the Reserve or Militia for the remainder of his engagement, where he will be available should his services be required in times ò national danger or emergency.

Sen/ry-Go.-There is one class of duty which the soldier has to perform, viz., sentry-go, which really teaches the men very little, and which has anything but a good effect on recruiting. I have always endeavoured to reduce this class of work as much as possible, and I consider that some of it, and that the most severe part, might be considerably lessened. It is especially at night-time that this duty presses hardly on the men, and there is no reason which $I$ am aware of why all barrack gates should not be locked from midnight to reveille, and only opened to those who have leave and privilege to return between those hours. It is quite unnecessary to have sentries on cold nights walking up and down between these hours. All gates can 
easily be made to connect with the guard-room by a bell, and the sentry, instead of being outside in cold weather, could well be permitted to sit in a chair at the fire. He could then be available to call the-noncommissioned officer and let the gate be opened. I invariably gave my men who had permanent passes, or who were granted leave to be out till midnight, to understand that they must return punctually. I did this not with a view of saving the sentry, as it could not lessen his work, but in order that the other men in the barrack-rooms who were fast asleep should not be disturbed by men coming in to go to bed between midnight and reveille. I do not see, however, why between the times named the sentry should not be'taken off the barrack gate. He learns nothing at such a time, and he can perform his duties just as well in the guardroom, and it is immaterial if he falls asleep in the chair at the fire. All he has to do is to call "Gate" if anyone asks to be admitted. It is difficult to see why he could not perform this duty just as well from inside the guard-room. There are, possibly, many places where this could not be done where sentries are in charge of magazines or other important buildings or Government property. In most barracks, however, my suggestion could be carried out, and a patrol going out occasionally would be a sufficient guarantee against any irregularities occurring.

Punishments-Bad Characters.-A paper such as this would not be complete without some refcrence to punishments, and how to get rid of bad characters.

First, as regards punishments. In the lecture to which I have referred, given ten years ago, I then suggested that the men should be fined in lieu of being made defaulters. I have not changed my opinion, and now would be an excellent time to bring in such a regulation. In the Royal Engineers, Army Service, and Departmental Corps, when a man is awarded confinement to barracks he forfeits his working pay in accordance with his rating. In the other branches of the Army a similar rule might wcll be made to apply, and let each man forfeit his messing allowance for each day's C.B. awarded to him. If this is done, crime in the Army would be gradually reduced to almost vanishing point, and I think one or two military prisons in a short time could be shut up-of course, the usual power of appeal, if it is considered necessary, can be given as in all punishments where a man's pay is affected.

Regarding the discharges of bad characters, it is a most difficult subject to deal with. The number of men tried by court-martial under Section 32 Ariny Act, re-enlisting after discharge with disgrace, is very large. They are sent away from one corps, but they soon turn up in another, as there are really no means of preventing them re-enlisting. Sometimes in their new corps they go on, well for a time-they are usually well known, but cannot be detected; and their case is usually one of in vino verilas; in their cups they let out who they are, and then the usual courtmartial follows ; they go to prison and are again discharged.

Here is an example of one of these men :-

He was first, as far as was known, in the Leicestershire Regiment, from which he was discharged on conviction of felony. He then went on to the 
Worccstershire Regiment, from which he was discharged with ignominy; he then joined the Lincolnshire Regiment, from which he was discharged with ignominy; he then honoured His Majesty's Navy with his presence for about eighteen months, from which he was discharged as a fraudulent entry; lastly, he was accepted and enlisted for the Scottish Rifles. Probably this man has been in many other regiments, but these are the only ones which came to light. There are two gaps of nearly three years and over four years in his career so it is very likely that during these seven years he was living somewhere in several other corps at his country's expense. A system of vaccinating all officers and men in the Army in some particular manner, or of photographing such men as I have described before they; leave prison, and then sending copies to each regimental district and recruiting officer, would greatly assist in stopping these re-enlistments.

(Since this paragraph was printed, a distinguished general oflicer has suggested to me that the anthropometric system which is so well worked in India for the detection of evil-doers, might be tried with these cases; another officer has pointed out to me that the Bourdillon system, so successfully carried out in France, might be made use of. Both systems are, I understand, well known to all anthropologists.)

This class of man causes an enormous expense to the State; but approving officers would, I think, discover more of them when they are re-enlisting if in all suspicious cases they would ask them in quick succession a few questions regarding their antecedents. These men generally fail in their geography because, of course, they are not telling the truth, and they never can or will identify themselves. I caught one man because he informed me he had walked from Flectwood into Lancashire-as a matter of fact he had not been near Fleetwood. Another said he had walked from Dublin to Armagh trying to get work, but in cross-questioning him it turned out he had been $z^{\prime} i a$ Belfast. When bowled out they then often confess, and a large shedding, not of tears, but of ink results, as a correspondence has to be opened with all their previous corps to get particulars regarding them. In this way I had the satisfaction in one year of having prevented eleven of these men joining the Royal Irish Fusiliers. I fear our system is a little at fault; officers who have anything to do with the recruiting for the Army are judged more by the numbers they enlist than the quality, and it does not seem to matter whether these men turn out to be frauds, as they are called in the Army. These frauds, however, are a great expense to the country, and a perfect curse to their corps, the commanding officer, adjutant, orderly-room clerk, and everyone concerned, and they deter many respectable fellows from making the King's Army a calling. While the eleven men above referred to were of necessity confined in the guard-room at Armagh, I gave orders that no recruit was to be made a prisoner unless he committed some very serious offence, to prevent their being contaminated by these men. These are some of the difficulties a commanding officer has to contend with. 
Good-Conduct Paj:-If, then, the men on enlistment are given a clear shilling a day, some few may ask, What is to be done for the steady soldier who extends his service or re-engages? At present good-conduct badges are given, the first after two years, the second after six ycars, the third after twelve years, and the fourth after eighteen years'. service. These periods would have to. be shortened to two years, five years, eight years, and eleven years. After the latter period I would suggest no further badges being given, as otherwise it will be found-that a large number of men will extend their service to 21 years with the colours, and if men do extend their service the pension they will become entitled to is a sufficient reward; all we require in a battalion is a leaven of old soldiers, it would never do to go back to the old system when all men stayed on for 21 years. They werc good soldiers and excellent fellows during peace, but I fear in war-time they would not be able to undergo the hardships of a campaign. We require a certain number of seasoned soldiers-a little of the long-service element -in every battalion, so that in time of war the Reservemen required to make it up to war strength should not exceed about one-third; if about 600 men in each battalion of varying ages from about 20 upwards are fit for active service, there will be nothing to fear; there would then be no risk at a critical moment of discipline suffering. It must be recollected that in war it is the greatest kindness to bring it to a speedy conclusion, and the way to do this is, having arranged for the wants of the Navy, to ensure our also having an efficient Army.

I may here perhaps mention that there were other points I had intended to refer to, but fearing my paper would be too long, and that I should exceed the limits of time, I struck them out. 'They were :-

1. The clothing of the Militia, the regulations concerning which are liberal.

2. The wear and tear of clothing at manœuvres.

3. The free issuc of some articles of kit periodically.

4. Barrack damages, which are no grievance, as nothing but wilful damage is charged for.

5. Passes.

6. Dining halls-a necessity.

7. Cubicles-a doubtful improvement requiring much consideration, and which if carried out throughout the whole Empire would cost from $f 6,000,000$ to $£ 8,000,000$; whereas a slight increase of floor space to each man would be greatly appreciated and would entail little extra expense.

8. A small room in each barracks, neatly furnished out of regimental funds, where the men could speak with their relations and friends when they come to see them; at present there is no suitable place in any barracks.

Ours is now a great Empire. The red patches on the map go on increasing, and it is well worth taking the trouble to maintain what 
is under our flag; and in order to ensure our possessions being kept in a state of peace and security, an efficient and sufficiently large Navy and Army are essential. To-day I have endeavoured to put before you some points in connection with our officers and men of the Army, the result of ten years' experience as a commanding officer, by which, perhaps, our voluntary system of procuring the personnel for the military forces of the Crown may be improved. Theır adoption will cause a small increase to the Army Estimates, but by the abolition of the conditions and stoppages, etc., to which I have referred, we shall have contented soldiers. The small increase suggested regarding the officers, if adopted, must have a good result; and if we can procure sufficient officers and men, that bugbear of - conscription, or any form of compulsory servicc, to safeguard our Empire, will be relegated to the distant-futurc. The purse-strings must be relaxed. Mistaken economy only costs far more in the end. We rightly endeavour to decrease our National Debt, but other nations have had to increase theirs to bring their Armies up to the standard of modern requirements. We must for a time suspend the reducing of our debt to do what is necessary for the safety of the King's Empire. The anxiety which thinking men had to go through fifteen months ago, when Lord Rosebery told us he supposed we should "muddle through as usual," must, not be repeated; and thus, if any scheme can be devised by which the fersonnel of our Army can be maintained, its organisation, equipment, training, direction, and being in a state of readiness, are not it task of such colossal magnitude as is imagined.

Nay I thank you, in conclusion, for the great kindness with which you have listened to me.

Colonel J. A. Furgcssox (late Rille Brigale) :-We hare not often, I think, in this theatre listenel to a more practical lecture. Those of us who hare followal Colonel Dooner's lecture to-rlay will, I am sure, be rerg glatl to cone licre ngain to hear him on the subjects which he has been unable to touch upon in this lecture. We of the Services meet here and talk orer our own affairs in what may be almost ealled strict privacy, becamse, although the l'ress are representel here, the pearliof wistom which fall from our lips are sclelom preservel! Therefore one sometimes gets an opportunity of saying what one must unt say through the Press. We onicers are not allowed to ventilate our opinions through the P'ress on matters under discussion. One would scorn to do it anonymonsly, and one may not do so under one's name; but we are not yet forbichlen to say in this theatre what we think is the truth. I arree generally with nearly everything which has fallen from the lecturer. I have only, therefore, noten a few points on which I venture to differ from him. If the lecture hall been written to-day insteal of some time ago, of course Colonel Dooner would have left out some things which he has read to us to-day, but the lecture had to be in print before this -weck, and therefore the lecturer had not had the advantage of reatling Jr. Brodrick's speech in the House of Commons the other night. Of course, we are all aware now that the $3 \mathrm{~d}$. a clay mesing allowance is to be giren to everylody" in future, ant erery soldier in the room must be glad that the recruit on joiuingr will unw get the messing allowance at once.

Colonel Dooxer :--That is the rery thing. speech.

Colonel Fengussox:- - That appcared in the Times summary of Mr. Brolrick's

Colonel Dooxel :-I hope rou are riglit. 
Colonel Fekgussos:-I lwpe I am right. We want to attract recruits, anil men want to know what they are going to get at once. It is the hungry boy wio wants the extra 34., and not the old seasoncl soldier. The seasonel soldier takes the extrit money out in beer, but the youngr soldier wants plenty to eat, and he wants the extra 31 . more than anybolly else. It scems such a pity to limit the 3 d. to those whom the commanding oficeraut the melieal ofticer say are 19 years of age and efficient soldiers. I thoroughly agree with the lecturer that the conditions of enlisting should be marle more clastic. It is a good thing that they hare been made more clastic in recent years. Sometimes one is tempted to say that two years would be a sullicient term to fix for efliciency. If a man is not an eflicient sollier at the ent of two years he must have a singularly ineflicient connuanding ofticer, and a rery bal adjutànt. The lecturer, we will all agree, is right in saying that the $A$ rmy is fulicrously small. A book which we do not reat as inuch as we ought, I am af rainl, and which one untst not nention here, says that " $A$ strong man armed kecpeth his palace, and his goots are in safety" ; but the st rong man whio is not armerl risks his palace, and his gools are in jeoparyly. It is a sacred duty for all of us who know what we are talking about to repeat again and again in this thentre, and whenerer we get a chance, that the dimy is perilously small for the neels of our great Empire. Jalk about an Island Power! We are a Continental l'uwer, aud unt only a Continental l'ower, but a Power whose dominions extend to five continents. It is a thousancl pitics that in the last few years, with perhipis the strongest Foreign Jinister the country has ever seen, we have paralysel the hands of that YIinister by not giving him sufticient men-we as a nation, I meau. IIe has been obligerl to feel that he cannot speak as he ought to do, as the Prime Minister of this grent Enypire ought to lue able to speak, because he has not enougl efticient uattalions at his back. We cannot be considerel to be in a satisfactory condition compared with France. We have a population of $\$ 1,000,000$, and Frince has a population of $39,000,000$, and yet France tmins difty tines as mily men as we do. The lecturer despairs of compulsory serrice in any shape or form. I think that the person who talks about conscription for thit country would be roughly handled, but 1 do believe that the Government woild do well frankly to reenguise the fact that every able-borlical man mut accept service in the Militia. Four tranings is what was laid down in Pitt's Act at the legiuning of the century. It wouth not be an oncrous condition to hy that down again. that every man shouh be compelled to ito this service in the Mlititia, so as to be qualitical to bear arms in his combtry"s defence. 'The lecturer puts our fighting mei at !01,000, but it must be rememberes that those numbers inclule Volunteers, who cannot le said to be trainel solliers in many cases; although many of the Yoluntecrs are extremely efieient, many are not. The leeturer, again, puts the extra force that we shall refuire for some yeari to come in South $\Delta$ frica at $5,000 \mathrm{men}$.

\section{Colonel Dooxels:-I said 5,000 in adlition to the former number.}

Colonel Fligussox:-1-think cren that is a very sanguine estinate. I am afraid that for a year or two we shall require a rery much larger force than $\overline{0}, 000$ men more thai before. In the masterly statement of Mr. Brodrick the other night, which I am sure most of us soldiers followed with great satisfaction, there were two great blnts which bear on the subject of the lecture. One is the maintenance of the army corps, which I think is a foreign will-o'-(he-wisp), and the other was where Mr. Brollicksaid that he proposed to replace certain British regiments in Colonial coalingstations with native troops. Having servel for five years in Colombo, I think it would be hazanlous to eintrust such an inportant plice as that to native troops. If it is consillered nceessary to have one European soldier in Iulla to erery tiro natives, none of our coaling-stations ought to be left without a good backing of British troops. The lecturer has tonched upon the compulsory retirement of offeers. It locs seem rers wasteful that officers in the prime of life, with ripe experience, hare to retire under a harr-and-fast age rule. The Germans laugh at us for it. I remember going orer the

1 This would solve the recruiting difticulty; as it is reasonable to expect that many: men would lass from the IIlitia.into the Army.-J. A. F. 
fortifications at IIetz when I was at the Stafi College with Colonel Jonslale Hale, and General ron Snyth, a Cockney by birth, who had been Quartermaster-General to Prince Frederick Charies, said that the Germans laughed at us for our hard-and-fast age rule. Surely the doctors night be consulted, and if a man is still actire, and perhaps can run a mile in six minutes, it scems a little hard to turn him out at a fixed

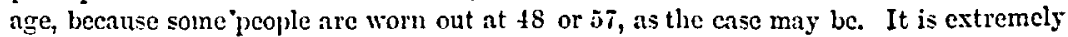
extrarágant, because we lo:c some of our best men while they are still thoronghly tit. As recards the training of ofticers, the lecturer is quite right in saying that we should do well to preserve both the Sandhurst system and the Militia system, but I do trust the authorities in their wistom will molify the present rules for the almission of oficers through the Militia into the Army. It 'does seem a great mistake that the school education should be mixed up with the professional subjects, aud that the two most important professional subjects for erery day duty-military law and tactics-hare been cut out. The new'Regulations are the despair of Public Schools and the ruin of the Army tntor. One suggestion I should humbly like to make, and it is really on an important subject. The regiments in India just now require some $\mathbf{2 5 , 0 0 0}$ or $\mathbf{3 0 , 0 0 0}$ ment to bring the reliefs up to date. One docs not sec how the recruits are to be found for these new army corps, or whatever you may eall them. Would it not be well to adopt the suggestion of Archileacon Wileon, of Manchester, male some fiftecn months ayo thiough the columns of the Times, and form military schools in clifferent parts of the country where the enblyo Hooligans or larrikins, call them what you will, the highspirited lads who are so much trouble at present in civil life, might, by being ciught young, say at the age of 14 or so, be tratincl as soldiers? They are very valuable material. We man the Nary with lads taken from matal schools, or trained on hulks. Why should not we inatu the Arny by means of military schools? I think that every County Coumeil and every great city should have a military school for the sort of laul I am describing. The lecturer speaks of getting more Hilitia officers, but is it possible to get many more? I doubt it very much. I heartily congratulate the lecturer on the most interesting and raluable lecture he has given us..

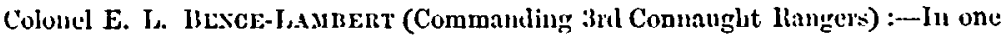
paragraph of his paper Colonel Dooner refer's to the question of regiments being calleal out at a time to suit themielres. I hold, with, I think, a number of other people, that the thing is to train these men si) that you will bave them in war-tinc. I am in command of a West Irelaut Silitia, anr we are dwintling in numbers. In ing opinion, this is greatly due to the fact that we have not a suflicient number of men to recruit from. I have spoken to Colonel Donner on the subject, and I think for curiosity it rould be rather interesting to show how in the counties from which my Hilitia comes $I$ am at the present moment recruiting from $2,000 \mathrm{men}$, and I hold that you cannot posibly keep a reginent properly if you only hase $2,000 \mathrm{men}$ to recruit from. If we were callerl out either early in the spring or late in the aut umn, in all probability we should be able to touch a number of men which we do not touch at present. The Midland Great Western lailway of Ireland have giren me these statistics with regard to what occurrel the year before last. They isned what we call harrestmen'r tickets, that is to say, men who come orer to England to labour in the fields, but it does not really matter in what time of the year they go. In February of the year before last they issucel $1,111^{\prime}$ tickets, in Iarch 2,514 , in April 4,166, in Yay 1,295, , in June $J, 145$, aud in July 137 , making a total of nearly 19,000. The majority of these are able-bodied men. Besides those, there aie from 3,000 to 4,000 men who go from Sligo, Ballina, ant Westport by ship to Scotluml and Eugland. Taking the German standard, where there is

'. Inal time pernittel I should hare liked to urge that the country wonld do well to replace the soldier's kit when unserviceable through fair wear and tear. Also that a handsome increase of pay should be giren to men who "exteull".their service; and that non-commissioned oflicers who re-engage with their commanding officers" approval should have their yay doubled after 12 years' serrice. In civil life emplorers know how to retain valuable serrants.-J. A. F. 
compulsory scrvice, and applying it for argument's sake to Mayo, it works out that about 1 in 10 of the population would be eligible for serrice. County Mayo therefore with a male population of 260,000 , would lare 26,000 able-bollied men to deal with. Of that number I have shown you that something'like 19,000 of those men go orer to England ench year, where they net from $£ 10$ to $\mathfrak{1} 12$. Unless you can call those men out when work is slack, Jou will not get them. We do not touch thent. We only get olld-job men, and it leaves altogether just $t, 000 \mathrm{men}$, from whom you have to deluct gentlemen and lawyers, which only learcs abont 2,000 men' from whom you can recruit. If we were callel ont at that time of the-year which suits these labourers when other work was slack, I hare no doubt whaterer that the regiment to which I belong could be brought up to $\$ 00$ men again. We ought, if possible, to try to suit the time. Of conrse, we shall be met with the question as to harrack accommodation, but that I have nothing to do witlı. The lecture las been most interesting to Militiamen, and I an very much obliged to Colonel Dooner for it.

Licut.-Colonel F. HasmersLer, p.s.c. (Commauding t th Lanciashire Fusilicrs):-The question is uot only one of providing recruits for the A my, but also of keeping them. The lecturer lias pointed ont that the recruit shoukl be made content, so that when he goes home he may bring back others. $\Lambda$ great deal of his contentment depentis on the good organiention of the battalion to which he belongs. A comfortable regiment is nlwars a striet regiment. That brings me to the question of non-commis-ionerl oflicers. Withont a proper proportion of non-commissionel ofticers it is practically not possible to keep up that supervision and discipline which are necessary to make a comfortable battalion. At the present day non-commisioned ofticers are taken away from their regiments for erery sort of thing. I do not say that the duties they fulfil are not useful, but still those men are lost to their battalions. lieeruiting oflicers want elerks. They senil to a battalion for.a clerk. Clerks are difficult to get, anil, as a rule, the only men who hare the necessary qualification for clerkships are the non-commissioned ofticers, who are taken away from their battalinns for that duty. The garrison police requires a scrgeant; a battalion las to find one. The duty which he has to perform in his battalion is to command a section, but he is taken aray to do cluty in the garrison police: His place has to be taken by somebody else, probably by a lance-corporal who knorss little or nothing about the duties of this important post-how important it is the war has taught us. The result is want of superrision, nud that learls to erime. So far as the regulations on the subject are concerncl, I think the organisation laid down in the King's liegulations could not be better, but with the slortage of non-commissioned oflicers in battalions it is practically impossible to carry out those regulations. The result is discontent amongst the men and a rery large wastage amongst recruits. A man who leares. the regiment through being cliscontentel, finding he cannot get on, keeps other recruits away. Sot only are numbers of non-commissioned ofticers taken awaý from their regiments for garrison duties, but many are necessarily employed on reyimental dutics-I refer to such men as the officer's' mess sergeant, the sergeants' mess caterer, thic post sergennt, ete. All these men hare definite lutics to perform in their companice, but they are taken away and other junior non-commissioned oflicers have to perform their duties as well ns their.own, resulting in those clutics being rnsher throngl and only half done. Of course, a large number have to be employed in aldition, especially at home, in training recruits. A great deal has been said lately on the question of captains training their companics. They are said to be wantiug in profesional spirit, and that they do not knon their work. That is not my experience. I hare the honour of commanding a new battalion. It ouly startal last Jlarch, and it is now over 1.000 strong. IIy captains would be only too delighted to hare the entire training of their companies if they could get them. But they do not get them. It is only twice a year, rluring field tmining and musketry, that they erer see their companies. It was only yesterday that I was talking to a captain of mine, an able officer in every way, who' has only recently returned from South Africa, full of zeal; he told me that it was heart-breaking the difficulty he had in getting hold of his men. I think that many of these duties might be performel by 
Reservemen.' In the caralry there is a system of rescrre squadrons into which all these non-commissioned ofticers aum men are put; the service squat'rons when they appear on parale are complete, and are really trained under their own squadron oflicers. I cannot armit for a moment that a company officer is not perfectly capable of training his own command if he gets it. We have already seen what they can do. Take, for instance, the case of the Nile Expedition. Company officers were started off in boats with their compnnies; many of the men having never handled an oar before in their lires, but they got through all right. We saw what company officers could to in the Egyptinn Army. Anylods who has seen the Egyptian troops knows that they are a very fine body of men and exceclingly well trained. That training is entirely done by officers holding the rank of company or squadron commanders in the British Army. We give an oficer a company of mounted infantry. He possibly knows something about ridling. and he may have been through a course himself; in the sjace of three montlys he turns ont a boly of men perfectly trained in a subject of which they had no previous knowledge. Colonel I ambert spoke of a battalion being reaty to take its place in war, but accorling to our present system it nerer is rendy, because until it actually comes to war many fighting non-commisionet oflicers and men are all over the place, doing anything but learn their trade as fighting men: how can they be expected to be efficient ?

Colonel Haxs Haymtos (Northumberland Artillery) :-We are all rery much indelted to the lecturer for the most interesting paper that he has laicl before us. I am quite sure what is greatly exercising the minds of the people of this country at the present moment is, how Mr. Brollriek's scheme for the increase of our Arny aml Militia (which he so ably laid before the House of Commons the other night) is to be carried out, withont, what is dreirled by the lecturer, and drealenl also by a great many people in this country, namely, conscription. This is one of the most important subjects which has been bronght before this meeting this afternoon. Realing' between the lines of. Mr. Brolrick's speech, in large letters is to be seen the word "conscription." How is the secretary of state for War to get the men he proposes sbould : be added to our Serrices? Will he be able to secuie them with the offer of extrn pay, or will he not? Anyone who suggests a practical scheme by which to aroil conseription, or to aroil what is a rery monlitiel form of conseription-I mean the ballot for the Hilitia-will rencler a great service to his country. I have submitted a humble propozal to the Isord Lientenant for the County of Northumberland, which, I beliere, in the course of a few ycars, would sove this country from conscription, and provide imany thousands of men skilled in the uie of the rifle. The idea occurred to me this way: I lappen to lire in a parish near London, and through the kindness of a friend I was allowed to see a copys of the records of a Court Leet leeld in the parish carly in the sixteenth century. "The record of what took place at this Court was as follows:- "At a Court Leet, held in the parish of ___ it is this day ordered that the constable in each township sliall see that every boy (in accorlance with the Acts of l'arliament therein provideal) who has reached the age of twelve years shall be suppliad with a bow and arrows, and shall attend at the butts." I ascertaines that between the reigus of IIcniry III. and Queen Elizabeth no less a number than cighteen Acts of Parliament were passed, haring for their object the tenching of the science of archery. We know that in the earlier times of Eilward I. the use of the bow was encouraged in every possible way. IIy proposil is (secing we have free ellucation in erery Voluntary and Board School (troughout this country) that every boy who reaches the age of twelve yenrs should be taught, not to fire, but to point a rifle from different positions. 'The

1 Ify point is that the administrative branches of the Army are intended, as I understand it, to minister to the wants of the fighting units, and should hare an establishment adequate to that duty. They should not be allowel to call upon fighting units to make up their deficiencics, thereby dangerously affecting the efticiency of the very units they are intendel to help, -F. H. 
experience of the last eighteen months during the war in South. Ifrica ought to be a lesson to us. If the handling of a rifle had been taught to the boys in our schools during the past fifteen years we should hare had at the present time tens of thousands of young men skillel in its use. The boys ought also to be taught, where it is possible, to ride. After many sears' experience and the study of our national requirements, I maintain it will be scrious neglect on the part of the members of the Government to which our Hon. Chairman belongs, if they do not forth with arrange that the military and clucational departments of the State combine to carry out this all-important safeguard for the defence of 'our country and its dependencies, and thus prevent conscription or ballot for the Srilitia in the near future. I necil not remind ladies and gentlemen present what was the result in centuries gone by of boys being accistomed to the use of a bow and arrows at the carly are of twelre years. History tells us that the British archer clistinguished himself in erery battle we fought, so I say that the Iritish rifleman would gain the clay for us in modern times if taught this seience in our schools. We have gathered much experience during the present war with regard to the reckless firing by our troops and the enormous and unnecessary expenditure of cartrilges. This was rery aptly illustrated the other day by an Irishnan-I suppose his name was "Pat" Atkins, not "Tommy" Atkins. He came home to his village in Ireland, having been in many engagements, fortunately without hurt. After talking orer his battles, a gentleman sid to him, "Well, Pat, what 'struck' Jou must in all the battles you've been in ?". "Well, your honour, to tell the truth, what 'struck" me most was the number of bullets that "missel' me!" There woukd be a iess number of bullets miss aul a much less expenditure of ammunition if we would only teach boys at an carly aye the science of bcing able to point a rifle properly. I commend that suggestion to the neeting, and 1 trust the present Gorernment will not delay many wecks longer without initiating this simple addition to the clucation of our youths. I an very glal that we are fortunate enough to hare a member of the Government present (Lord Raglan), who takes the deepest interest in the welfare of our Army and lieserre forces, and, perhaps, he will use his influence to ventilate the proposal which I have enclearourel to place before this meeting. Another matter, which is also a very serious duestion for the taxpayers of this country, was referred to by the lecturer, namely: Are we prepareal from a military point of riew to receire an inrarler? I submit we are absolutely unprepared. What can be a greater in ritation to any of our neighbours in Burope to invaite us thin the state of unpreparelnes;, from a military point of view, of our const defence? We possess at the present time few, if any, proper molern guns of position and no mobile modern guns, and therefore our generals can provide no adequate scheme of defence. I regret to say the reason why we hare no molern guns is the neglect on the part of the prerious Gorernmentand, indeed, of all Governments in the past. The guns are being manufactured now, $I$ understand, but I am advised that it will take six or seven ycars to supply this country with proper and sufieient mobile mo:lern guns to repel an inrasion by a Continental Power. We, as taxpayers, are cutitled to look to our Gorernment to secure this country and our homes from being railed. We want reasonable sifety. Have we got it? I say, absolutely, "No." I do not blame the military authoritics, because I have no donbt our generals hatre made out such schemes as are possible, without the necessary moleru mobile guns. We know from General Mercier that it very near neighbour made every preparation last year to laut troops in this country. The fact that we are unprepared is an open invitation to an unfrienclly Power to land troops in this country. If we were properly preparet no foreign Potrer would erer dream of making raids upon our consts. There are three inportant and pressing matters which I trust will be dealt with at an early date by Parliament and by the Commander-in.Chief. First, what I have already referrel to, namely, the teaching of erery school boy who has reachel the age of twelre sears the way to point a rifle from different positions, aud thus prerent conscription in the future. Sccondly, the supply of mobile nodern heary Q.F. guns, and mobile light Q.F. guns, to arm and properly urganise a mobile coast forec for the defence of the south coast of Englanl. and thus 
assist in securing the mobility of out fleets. Thirlly, the storing an:l maintenance of sufficient foor stuffs in this country for; say, eighteen to twenty-four months ahead, to prevent panic and starsation in time of war, and again further secure the mobility of our flects. I shall be surprised if my first and my third proposals are not discussel in the House of Commons at an early date. Iy second proposal I fecl sure is receiring, and will reccirc, the carnest consideration of our new commanter-in-chicf, Lord Roberts, and will be carried out. There are other points which I should have wished to have touched upon, but, as ajy allotted time has gone, and no doubt there are other oflicers who wish to address the meeting, I will only thank you for listening to the few remarks I have made, and I would again testify to the usefulness of the paper the lecturer has rearl to us.

Licunt. Colonel W. C. E. SERJwast (oth Battalion Rifle Brigatle):-I nnly propose to say a fer words upon Colonel Dimner"s very able paper, which has probably more thoroughly grapped the guestion than has any other paper that has erer been read before this Institution. The lecture is more or less connected with the Service to which I hare the honour to belong, riz.. the Militia. The Militin depends mainly for its recruits on the boy who cannot get work and on the old soldier who cannot get employment; as far as the boy is concerned he may be all right in his was, but his position in the Militia has not been make as pleasant for him as it might lare been. There is possibly a reason why the authorities hare not hitherto thought it adrisable to extend crery consideration to the Militia, for the boy in question is practically $\mathrm{com}$ pelled to join the Regular $A \mathrm{rmy}$ in order to obtain a more pleasant sphere wherein to utilise his military preclisities. With regard to the ofliecrs, I think you will nerer hare any difficulty in getting them. The system of selection which has been exerciscd during the war in South Africa may possibly tell somewhat on the future supply of Militia officerg. Some officers may say, "We belong to a unit which, as a battalion, has taken great interest in practical solliering, and, at incrensed expense, we hare frequently attended the manourres. We hare been well reported upon as Militiamen ; we act as Regulars in time of war, ancl we think, therefore, it is only reasonable that we should hare been selected for the particular post of honour, viz., actire service, while other battalions who possibly hare not rone as well as we have, and who have unt attended the manœurres as we hare, have been selected in preference to ourselres." That is only a reasonable position to take up under the circumstances. But no doubt with our new organisation and n!ministration at the War Oflice all these details will be set right. Broally speaking, I contend that the question of obtaining oflicers and men for the King's Army is one of $£$ s. l. . If you want a gool man in any walk of life yon hare to pay for him. If you want a solctier who is a. man of intelligence, a man who possesses potentiality, and is capable of receiring any technical knowledge an instructor inay wish to pour into his brain, you must pay him accorling to the capacity of his intellect. The same remark applies to oflicers. One of the spenkers dropperl a hint about the Bar. I have known something about it, as I laare also about the Auxiliary forces for nealy a runter of a century, and I can say that in 1 o profession can a man do better than at the Bar if he knows his work. Why! Because lie gets a chance. It is the same with the soldier. If you procure a capable man; soldier capable of receiving instruction, all his instructors hare to do is, ats Colonel Hammersley pointel out, to apply a certain amount of time in a reasonable way, and excellent results should be obtained. That is what you pay for, and what you must pay for. With regird to ways and means, one speaker spoke of incrensing the rates in respect of techuical and military clucation.

Colonel Hasultox :-I only wished to strengthen the gentleman's argument that boys elucated at the expense of the country could fairly be asked for some retum in the shape of irill.

Lieut.-Colonel SERses: :-Quite so, Sir; but I was going to mention that all the necessary funds can be obtained for increasing the military efficiency and the forces of the country without in ans way drawing upon the rates or eren upon the taxes. That 
is a tall statement, I. know, but it is I fact. Anyone who is engagel in large commercial transactions, or who is conversant with the methods adopted in the handling of millions, not only in this country but elsershere, will tell jou that the greatness of the commercial prosperity of England depends upon the magniturle of her national debt. Consequently the more you increase the national debt within practical limits, the greater will be your international credit and the more powerful your financial administration. That is an absolute truth. If you double the pay of your soldiers and considerably increase your Army, you will then hare an effectire commercial asset. Quarlruple the pay of your officers if you like. It does not matter what you pay them in reason, because you can afford it. In industrial and in other branches of finance there are nien in our midst to-day who are making millions and unillions, whom taxation cannot adequately touch. These are the men who do in reality manipulate your commereial assets for their own purposes, ame these, I content, are the men whon shonld alequatcly pay for the support and maintenance of our military forces.

Captain R. J. JaACDoxxedL (late 81st Regt.) :-I think the question of providing men, especially for the Army, is one of the most important that could possibly take place at the present time. The lecture is most able and practical, and, I hope I may be allowed to say, most acceptable at the present moment. It seems to be acknowleigel by Colonel Dooner that the word "conscription" will nerer be entertained by the people of this country, that thes will nerer recognise conscription. Of course, the way in which the people in this country would recognise conscription would be through the action of the House of Commons, and the Gorernment of the day, when it becomes a question at an election. At election-time the question, should it be raiserl, will be fought out at one clection. Thequestion has been asked : How is conscription to be aroiled ? am going to fall in with Colonel IIamilton's view. It ran be aroided by going to the root of the thing, by educating the youths of the country. If military instruction had been renclered obligatory when national elucation was establishel, this question would not have arisen, because all "youths" would, in the same way as they receire ordinary elucation, reccive a certain amount of military instruction which rould qualify them for taking their place in the defensive forces of the country. This is not a new fal of mine. Fleren yeais ago, when Iord Wolseley was Adjutant-General, I put the whole matter before him. He was very sympathetic with regard to the question of the training of youths. I hal the honour of an interriew with him, and he said; "Can't you get someboly to take it ip? " I never hare been able to get anyone to take it up: and I do not know that it has been taken up. There is the Lads" Leaguc, the Ladls: Drill $A$ ssociation--and a rery useful Associntion it is. I hold the riew very strongly that every male, between the age of 14 and 17 , as he grows up ought to be prepared by the nation .ant free of charge to take his place if called on in the defence of the country. Passing from that, I come to the question of what is to be done. At a Schnol Board election in the district in which I reside, I wantel to get the gentlemen whom we returned, to pledge themselres and the Board Schools to tale this question up as a matter of cducution. No one can contradict me when I say that if fou teach boys when they are young the ruliments of soldiering, the rudiments of aiming and learning how to fire-I will not go so far as to siy firing-as years roll by it becomes engrainal in them and they will wish to know something more albout it. If this were done, you would have the volunteer force increased three-fold. 'Isut whether you had the Volunteer force increased three-fold or not, crery youth, when he grew to manhood, would have a certificate of some sort that he had receired a certain amount of military elucation. I do not know what kind of certificate it should be ; I leave that to those gentlemen of light and leadling who become Cabinet Jinisters, those who look after.our interests. It is for them to derise the means by which these ileas are to be carriel out. It certainly seems to me-aul I say it bere amongst men of influence, who I hope will exercise influence outside on public opinion-that the time has arrivel when erers young man should be called upon to take his place in the defence of his country, and a system of "Obligatory Uilitary Instruction in all Schonls for Jales" should be passed into Law; and which might well be coupled with the course of physical training which is at present giren in Board Schools. 
Colonel Doossi, in reply, said :-I do not know that there is any point which I have to answer in connection with the lecture. None of the speakers, I think, hare disagreed with any statements I hare made. I certainly do hold to what I sail about conscription, that it has not, in my opinion, yet come within the range of practical politics, because, as I say in my paper, as far as I know, no member of Parliament or candidate for Parliament has yet referred in his address to such a subject. Therefore the point is in the future, and, as the last speaker obserred, would have to be fought out at the polls. Of course mine is only an opinion, but in my riew the candidates who say they will rote for conscription or any form of compulsory service will cut rather a sorry position at the declaration of the poll. I think no form of compulsion should be adopted until we have giren the voluntary sjistem what I call a fair chance. It nerer has had really a fair trial. ("Never.") I am old enough to remember when a man ouly drew td. or sd a day ; then it went on to 6d. and 7d. Then we paid the nien weekly, and it got to about 4s. Gil. or something like that ; but what I submit it should be, is : a clear shilling a day on enlistment. I am surprised, and at the same time delighted, to hear Colonel Fergusson sas that every man who cnlists is in future to get his clear ls. a day, but I will ask Colonel Fergusson to beliere it when he sees it. I read erery word of Mr. Brodrick's speech of last Friday in the House of Commons, but I certainly did not see anything in it which said that he intended giving all men on enlistment is.a day. He did not mention anything about abolishing the age or the efticiency condition, and that is what Colonel Fergusson, I think, Las failed to obserse. I hope he is right and that I am-wrong, Colonel Benec-Lambert said that 19,000 men come orer from County Mayo each yeai. thereby lessening the chances of recruiting for his battalion. As we know, the West of Ireland battalions are in rather an unhappy condition in the matter of their strength being so rery much below their establishment. I think the authorities shonld consider whether it would not be all risable to call the regiments in that part of Ireland out for training sometime in $A$ pril or earlier, so as to get the training over by at latest the lst June. That would, I think, gire Colonel Bence-Iambert and other commanding officers in the West and North-West of Ireland a better chance of bringing their regiments up to establishment. We all agree that the bountics ought to be increasel; and as appears from Mr. Brollrick's speech this will now be done. The bounties to Jilitiamen will for the future be rery fair, and the men will be well deserring of the increase, because they will be ready at a moment's notice to come out and fight if required. The returns of the Reserremen who,joinel when they were called out prored conclusirely that we can rely on the Reserre, and that the men are there when we want them. With regarl to what Colonel Hammersley said about the non-commissioned officers being taken from battalions, and captains being unable to get their companies together: the difficulties that commanding oflicers have to contend with are rery great. Oficers have an uphill battle with all the duties which have to be carricd on, and when their non-commissioned ofhcers are taken away from their legitimate duties, the trouble is still more increaser. Of course, down at Chatham we hare had considerable difficulties to contend with; because there has not been the usual garrison there to draw npon. I hope, howerer, that when we hare got the full strength Colonel Hammersley's difficulties will not be so great as he has mentioned.

Colonel HAJMERSLEY :-My point is that the regiments ouglit not to be drawn upon at all ; that the regiments of the fighting unit and all the administrative branches should be of sufticient strength without drawing upon the fighting units.

Colonel Doosen:--Of course that is a great point, and everybody will agree with it, but there is certain work which has to be carried on in garrisons, and it is owing to the garrisons themselres that this is so. For instance, Colonel Hammersley has mentionel garrison cells and other duties of that description. Of course the authorities naturally draw upon the regiments to furnish the necessary staff in order to sare money. 1 agrec with Colonel Hammersley that it is not a gool or an eflicient way of managing these matters, but it cannot at present be aroiderl. Colonel Hans Hamilton asked who is going to propound a scheme to aroid conscription. I say that our voluntary system up to lhe present has certainly savel us from conscription. All 
I want to argue is that we should take care that the men when thes are enlisting should get a fair rate of pay; and I consiler if we could only say "Your pay is a clear shilling a day ; do you want to enlist or not?" we should get sufficient men. I think that is the way we could aroid conscription-to try and get contented soldiers. Let the men tlien go out amongst their friends, and you will find that they are the best recruiters for the King's Army. I think Colonel Hamilton mentionel something about the Gorernment wishing the regiments not to recruit up to their strength. I fear there must be some mistake, but $I$ imagine the answer is : our organisation being 8 companies in the battalion, althongh I know there are some battalions wbich hare 10 or more companies, the authorities naturally do not want, if possible, to hare battalions differentls organisel. After all, had Colonel Hanilton been allowed to increase his bat talion it, would not remely the difficulty. There might be the numbers, but without any proper organisation.

Colonel Hayintos:-I submit that would not be so, because the taxpayer is entitled to hare the 130,000 men he is realy and willing to pay for, and for which the moner has been roterl.

Colonel Dooser :-Colonel Hamilton is right when he sass that the total is 130,000 men. But the authorities distribute that orer all the counties of Great Britain and Ireland. and, unfortunately, if one county fails, as in Galway or Wayo, to recruit its proper number, the authoritics cannot well go and add on a company or half a company to another battalion where recruiting may be satisfactory, and at the same time make the organisation-shall I call it-more or less, rilliculous ?

Colonel HajnLtox:-It has been so always. This is not the only instance. I am reminded of other instances where the country has not been properly treated by the Gorernment. You want men. The taxpayers are prepared to pay for these 130,000 men, but they hare not been recruited, and where commanding officers were realy and willing to recruit then, they were refused.

Colonel DooNer :-Of course the only way of getting out of the difficulty, if the authoritics siw there was a chance of getting the requisite numbers, would be to hare two battalions in the particular place where Colonel Hamilton refers to. The point which Colonel Hamilton, I think, misses, is that one conmany tacked on to a battalion would be no proper organisation. I do not think there is anything more for me to say, but before I sit down may I again thank you all very much for the kindness with which you have listened to me, and express my gratitule to those who lave so kindly jnined in the discussion.

The Chainmax (Lieut.-Colonel Lord Raglan):-It is usual, I beliere, on these oceasions for the Chairman to sum up the discussion; but as time is getting on I will not detain you, except to refer to certain points where there appears to be some little difference of opinion. Colonel Dooner has giren us a most able lceture, but with certain remarks of his I do not agrec, and there are certain other points in regard to which I can perhaps show lim lie lias received a wrong impression. With regard to the question of the messing allowance for young soldiers, I woull point out that it is hardly fair to gire a man who has just joirici, and who does not know the butt-end of his ritle from the muzzle, the same pay as you give to a trainel soldier. In the boy's own interest it is not adrisable that he should hare too much money in his pocket. Thireepence does not sound rery much, but a few pence more or less is apt to mean another pint or two, and that may lcad to the Guarl loom. We do not gire our sons, when ther first go to the Unirersity, the same allowances that we gire them a little later on in life. Coming to the question of the army corps, Colonel Dooner seems to think that because we propose fo keep three army corps more or less rendy to embark on foreign serrice, we are going to keep ships perpetually somewhere-I do not know where-to take the men abroul. I believe there is no room in our harbours for all the ships of the Nary, and if we are going to fill up the harbours with a large number of transports I do not know what would occur. Then 
thele is the question with regard to the pay and allowance to Militin oflicers for groing through classes. Last sear vers consillernble adlditions were nuale to the classes anth to the schonl; for attending which Yilitia önicers receire pay and allowances They etul ales now be attachesl to reginents for the purjme of refreshing their knowledge at intervals in a way nerer allowed before, receiving the pay and allowancesof their rath. I lope that system may be still further exteucel.

Coloncl Dooxer:-I hope ther will be allowel to go to the higher things-to (ii). What is hail down in the Regulations as (C) to (G), thereby giring them soms encouragement to pass the examination which all captains in the Regulars hare to pas:

The Chaingas:- - I hoje we are moring in that direction. Witl reganl to the quation of Militia bountics, of course Colonel Dimmer was not.aware of them when he wrote his lecture. I beliere he approves of thetn. The syitem proposel for Iilitia bounties is that the Militiaman will receire 30 s. after encli training and at $£ 3$ bounty between his sccond and his third training and after every subsequent trainine. This will probably be given at intervals in sums of $\mathcal{L} 1$. That will be a subitantial sum for a man to reecive; and you will have the alditional alluantage of kecping in tonch with the men during the non-tnining periol. The fact that you lost sicrlit of your men for 10 or 11 months in the year has always seemal to me the weak spot in the Militia. Colonel Dooner alludeil to the cmplnyment of lisclingred soldiers. There is one point with regarl to that, riz.. the giving of characters to the men, which I would press upon officers present. One's idea is to lie kint to a man. But if you give a good chnacter to a bau man and that man obtains a position of trust by that good character, which he is not worthy of, and fails in that prosition of trust, you do a most incalculable harm to the soldiers in the Arnis who have a gool character, and possibly you block that arenue of employment for ever to all other old soliliers. 1 daresing that Colonel Dhoner noticerl in the secretary of State's specch no Firday that he alluded to "Sentry-ro" as being one of those things which he himself particularly wanted to sec reduced as much as possible. Haring servel in a regiment in which a rery large number of men were employel on guard, aud where the nen got rery few nights in bed, I know the evils of it. First of all, as Colonel Dooner sase, it is no instruction to a mun, and seconelly, it is physically most detrimental to him. I hope we shall reluce the duty of "Scntry.go." With regard to the sentry at the barricks gate, I should like to see him in bet. I lo not know about the question of fire, except that statistics show that by farr the greatcr number of fires occur betwecu the hours of $S$ and 10 oolock in the erening. If that is the case, the sentry might probably go to bet after the fire time hat elapsed. Then there is the question of fine:. There are many occizions on which it woull be a rery excellent thing if jou could fine a man, but I dacsiby Colonel Dooner is aware, as $I \mathrm{am}$, that it is a point of lonour anungst men to treat a mall who is umler stoppagcs; his frients are rely sorry for him and their sympthy is apt to take the shape of beer. I shoull like to say one worl with regunl to proferional descrters. Thesc men give endles; truable. We know that one bish nian in a company can nearly ruin that company. One of these professional deserters and bal characteri can do an inculculable amount of Larm when he is put in a barrack rom with 18 or 20 recruits. If some systein conld be devised whereby these men could be illentified and conld be presentel from entering a fresh reriment, it would be an inmense alvantage in every possible way to the Army. Colonel rergusson alludal to the question of native troops being used at coaling stations, antl he said that he objected to that course being adoptecl. Tlie tronps in tho:e coiling stations will not be natires of those stations, but will be natires of Inclia. There are no finer men on the face of the earth than our Indian trọopis, and they are perfectly ceppable of doing the work of guarding such places as Singapore, where welnve hitherto locked up expensive European troops, which might liare been rery nuch better employel elscwilicre.

Colonel kengussox:-I only meant that in the erent of their haring to face a. fureign l'ower it would be prulent to gire them a backing.

vol. XLV. 
The Cifalmuar:-That they will get Irom the Nayj. Colonel Fergusson secmed to think that the proposel new army corps Army. That is not quite so. The object of the new organisation is to better utilise the men which we hare now got rather thals to adll adlitional men that we hare no means of utilising. Some years ago I got out the proportion of Militiamen to the male population in erery county of the United Fingdom. The results were remark. able; but nothing struck me more than the fact that on the West Coast of Ireland, where work is short and labour is exceedingly ill-paid, the proportion of Militia was so small to the male population. Colonel Lambert has told us that the men come orer to Eugland for the harvest, and I am inclebted to him for this information, which explains a matter which has puzzlel me. Then there is the question of cmployed noucommissionel oflicers, which Colonel IIammersley has alludel to, and which we bare all known and deplored for years. I renember one particular case years ago. The commanding ofticer of a certain reginent at the Curragh went to the brigade major aud said: "The number of employed men in this garrison is something perfectly appulling! Eight men lewve uy batracks every morning to gro up as onlerlies to tle brigale oflice." The brigale niajor sail : "I have never seen one in my life, except the brigate orierly." lherefore, for munths, and probably for yars, scren men had been employel at the brigade oftice, Hearen knows at what, and noboly knew anything about it. It was only the fact of a ner commanding oflicer coming in and making a row that these seren lost sheep were discorered. If officers would watch these things a little bit more these cases wo uld not eo often occur. I hare hal many talks with my olil friend Colonel Hamilton, with regard to training boys. It would be a very excellent thing if every bos could hare some military training; but it is no usc having trinet men of any sort unless you hare some organisation to put them into.

Captain HACDoxiser, :-Mag I interrupt with one obserration ? Could you not get the Gorernment to carry that out and put the boys into some sort of corps?

The CHanksax :-The question of enploying these boys when jou hare tiainel them is one of great trouble and very considemble expense, becausc you must have some organisation to utilise them. Colonel Hamilton was a little hard, I think, ujюn Mr. 13rolrick about the $50,000 \mathrm{men}$. The $50,000 \mathrm{men}$ are an aldition. The $50,000 \mathrm{men}$ which Mr. Broulrick alluded to are to be a ncw Militia Reserre-a real lieservetotally apart from the establishment of Militia, which, we hope, the new bounties will tencl to raise to its proper number.

Colonel Haynutox :-I withelraw what I stid, but mas I ask, docs that mean that the Militia-plus the 50,000 Reserre-will be 180,000 men ?

The Cusirmax :-I hope it may rise to that.' I do not think there is any other point I need trouble you with. I will only allude to that which apparently is a bugbear: to many gallant gentlemen who hare spoken here to-day-the question of conscription. Someboly said that no public man had ever alluded to the possibility of conscription. I would only refer this gentleman to Mr. Brodrick's speech last Friday. I am norry to l:are cletaincel you with my remark: for so long a time, but before I sit down I think yon will agree with me in thanking Colonel Doouer for his most excellent lecture, to which we bare all listened with great interest, together with the instructire discus. sion which it has proroked. 